238 肺気腫症例を対象とした呼吸性動態解析

金沢大学・医学部保健学科田中利恵, 真田 茂, 鈴木正行 金沢大学医学部附属病院・放射線科 小林 健 金沢大学医学部附属病院・放射線部松井武司 金沢大学医学部附属病院・検查部 南部裕子, 大場教子 キヤノン(株)宇都宮光学機器事業所・DRシステム第 5 開発室 井上仁司

【目的】大視野の動画対応フラットパネルデイテクタを用いることで 胸部X線動画像を取得することが可能となる。そこで解剖学的情報 に動態情報を付加するアプローチで診断情報の増加を検討した。本 研究の目的は, 胸部X線動画像を対象に呼吸性動態を定量化するコ ンピュータ解析法を開発することと, その解析結果と既存の検查法 による結果との相関性を解明し，本法の有用性を評価することであ る。

【方法】キヤノン社製CXDI-22改造機で肺気腫症例掞よび正常症例の 呼吸過程を撮影した(撮影条件：110 k V，80mA，6.3msec，アルミ 付加フィル夕： $2 \mathrm{~mm}, 3 \mathrm{fps}, 10$ 秒間, 撮影体位: 立位正面背腹 方向)，胸部 X線動画像 (マトリックスサイズ $2688 \times 2688$, 階調 12bits)の肺野領域認識掞よびフレーム間トレンド補正を行い，肺野 ごとのピクセル值の変化を測定した。また, 得られた結果と呼吸機 能検査結果㧍よびCT検査所見との関係を調べた。

【結果および考察】正常症例では肺野内局所のピクセル值は呼吸位相 に同調して変化した.しかし, 肺気腫症例ではピクセル值の変化が 小さい部位がみられた。そして，その部位にはCT画像上でAir trappingが認められた。またAir trapping周辺の肺紋理動態画像情報は 外科的手術の適応判定に有用であった。これにより動画対応フラッ トパネルディテクタによる胸部X線動態検査および本解析法の臨床 的有用性が示唆された。

\section{9 呼吸位相における横隔膜の形態および位置の解析}

金沢大学・医学部保健学科武田斐子, 真田 茂, 田中利恵 金沢大学医学部附属病院・放射線科 小林 健 金沢大学医学部附属病院・検査部 南部裕子，大場教子 【目的】大視野の動画対応フラットパネルディテクタ (FPD)を用いる ことで胸部X線動画像を取得することが可能となる．われわれはこ れまで呼吸性動態の定量化法の一つとして, 横隔膜除影の最上部の ある一点の呼吸による移動量の変化を計測してきた，しかし，位置 の変化のみの計測では呼吸機能を評価するには不十分であった。そ こでわれわれは，横隔膜全体の動き，形態に着目して胸部X線動画 像を対象とした呼吸による横隔膜の形態および移動量の変化を計測 することを試みたので報告する。

【方法】キヤノン社製CXDI-22改造機で正常および呼吸器系疾患被験 者の努力呼吸過程を10秒間撮影した(撮影条件: $110 \mathrm{kV}, 80 \mathrm{~mA}$, $6.3 \mathrm{msec}, 3 \mathrm{fps}$, アルミ付加フィル夕 $2 \mathrm{~mm}$, 撮影体位: 立位正面背 腹方向)。胸部X線動画像 (マトリックスサイズ $2688 \times 2688$, 階調 12bits)をパーソナルコンピュー夕(OS：Windows 2000(Microsoft), 開発環境: C++Builder(Borland))に転送し, 各呼吸位相に㧈ける横隔 膜の形態抢よび位置の変化について解析した，正常症例16例，異常 症例 5 例に対して計測を試みた。また，生理学的呼吸機能検査との 相関性を調べた。

【結果および考察】呼吸による横隔膜陰影の形状および位置の変化を 定量的に解析することができた，異常症例では，正常症例に比べ横 隔膜の形状および位置の変化が小さく, その結果は呼吸機能検査と の相関がみられた，症例数を増やして，定量デー夕の評価法を確立 することによって, 本法は慢性肺気腫, 間質性肺炎などの呼吸器系 疾患を簡便に評価できる可能性がある。
240 動画像認識を応用したX線透視画像の運動解析ソフトウェア の開発一食道透視画像での検討 -

東京都立保健科学大学・放射線学科根本茉莉江，妹尾淳史

【目的】X線透視による食道造影検査はバリウムの通過が早いために 診断が非常に難しく医師の経験や技術が必要である。そこで，今回 われわれは動画像認識を用いて透視画像から食道壁運動を解析し診 断支援に活用することを目的としたソフトウェアを開発したので報 告する。

【方法】画像解析は動画像認識法のうち，ノイズに強いといわれてい る空間的大域最適化法を用いて動きベクトルを算出した。動きベク トルは連続画像から隣り合う2枚の画像を取り出し画素ごとに算出 した．動きべクトルを臨床でより理解しやすいよう向きは矢印で， 大きさはカラーで表示した。

【結果および考察】今回われわれは動画像認識を応用した運動解析ソ フトゥエアを開発した，食道透視画像から食道壁運動を簡便に可視 化できた。今後はより沉用性が高く操作性を向上するよう改良し, 症例の検討を重ね, 正常と異常な食道壁運動を比較検討していく必 要がある。

\section{1 肩関節正面 $\mathrm{X}$ 線動西像による外転運動の解析}

金沢大学・医学部保健学科長谷川顕司, 真田 茂

金沢大学医学部附属病院・整形外科 北岡克彦

【目的】現在, 肩関節検查では単純X線撮影, CT, MRI, 超音波など さまざまな撮影方法が行われているが，これは肩関節の静態情報を 与えるに過ざない。近年, フラットパネルディテクタ (FPD) 装置の 進歩により容易にX線動画像が取得できるようになった。そこで動 態情報を含む新しい撮影法や，その動態情報を定量化するための解 析法を検討した。本研究では肩関節正面撮影において, 肩関節を外 転させたときの動態解析を試みた。

【方法】正常被験者の肩関節正面像を動画像対応FPD装置によって撮 影した，肩関節を自然下垂位で体側につけた状態から最大外転位ま で移動させる側方挙上運動を用いた。得られた画像から上腕骨長軸 と垂直軸のなす角度 (Arm angle) および上腕骨長軸と曰蓋縁のなす角 度 (Glenohumeral angle)を求めた。外転角度の変化とArm angle㧍よ びGlenohumeral angleとの関係をグラフ化した。

【結果とまとめ】Arm angle, Glenohumeral angleの運動変化には左右 および個人間では有意な差がみられなかった。また, Arm angleと Glenohumeral angleは外転角度にほぼ比例していた，本撮影法㧍よび 解析法によって, 外転角度の变化による正常な肩関節の動きを定量 的に把握することができた，今後は異常症例を対象に解析し，新し いスクリーニング検査としての有効性を検討したい.

\section{2 乳房CR画像診断支援装置 (CAD)の)腫瘤影に対する判別処理 の評価}

国立がんセンタ一東病院·放射線部 高田敦子，永井優一，福原里恵 田仲 隆

【はじめに】乳房CR画像診断支援装置(以下，CAD)における乳癌候補 陰影の検出過程に腫瘤影の判別処理がある。判別処理の精度は診断 業務の効率化に直接寄与する最も重要な過程の一つと考えられ, 高 度な処理技術と判別の正確さが求められる。

【目的】CADの乳癌候補腫瘤影に対する判別処理の評価を行ったので 報告する。

【方法】乳房ファントムを用い, 厚さ, 形の異なる自作模擬腫瘤(良悪 性を考慮した腫瘤)を撮影し, CAD処理の結果より判別処理の評価 をした。更に臨床の処理結果との比較も試みた。

【結果および考察】自作模擬腫瘤の結果は悪性の腫瘤影および判別し にくい腫瘤影(カテゴリー 3 以上) は検出し, 良性と考えられる腫瘤 影(カテゴリー 2 以下)は検出しなかった. CADが腫瘤影の形態的特 